\title{
Good Governance, Efficiency and the Provision of Planned Land for Orderly Development in African Cities: The Case of the 20,000 Planned Land Plots Project in Dar es Salaam, Tanzania
}

\author{
Joseph Mukasa Lusugga Kironde \\ School of Real Estate Studies, Ardhi University, Dar es Salaam, Tanzania \\ Email: lusuggakironde@gmail.com
}

Received 17 November 2015; accepted 6 December 2015; published 9 December 2015

Copyright (C) 2015 by author and Scientific Research Publishing Inc.

This work is licensed under the Creative Commons Attribution International License (CC BY).

http://creativecommons.org/licenses/by/4.0/

(c) (†) Open Access

\begin{abstract}
In many African cities, governments have been unable to provide sufficient appropriately located and priced planned and serviced urban land to meet demand. As a result, informal settlements are growing faster than the rest of the city. Efforts to deal with this situation are hampered by several factors including lack of resources to acquire and service land to forestall haphazard development. In 2003, the Ministry of Lands, using borrowed funds from the Treasury, undertook an ambitious land servicing project in Dar es Salaam. The aims were to: alleviate the shortage of surveyed and serviced urban plots; tackle the rapid increase of informal settlements; control land speculation; address corruption; complement the national drive to reduce poverty; develop satellite towns; and implement the ruling Party's manifesto on liveable human settlements. This paper evaluates this undertaking from a good governance point of view. The Project was efficiently implemented. Over 40,000 plots were produced and sold; the invested billions of shillings were recouped several times over; and replication was enabled. However, it increased poverty among those whose land was acquired; and fuelled the growth of informal settlements. With less than $17 \%$ of the plots categorized as low cost, the Project was not pro-poor. Outcomes included the realization that land had value that could be unlocked with servicing. This has spawned several projects involving servicing land for sale, undertaken by other authorities and the private sector. This, however, is excluding low income households. The Project's achievements were realized at the expense of good land governance exemplified by: lack of coordination among key players; shortfalls in transparency, public participation, institutional decentralisation and inclusiveness; and neglect of environmental fallouts. Low income households were in practice excluded from this and subsequent money-driven land delivery schemes, a trend that needs to be reversed to avoid social polarization.
\end{abstract}




\section{Keywords}

\section{Planned Development, Cost Recovery, Good Governance, Exclusion}

\section{Introduction}

Many urban authorities, ranging from the central to local government or public agencies do once in a while undertake to provide land that is planned, usually with a claimed aim of dealing with slums and providing land for low income households. In the mid-2000s the Government of Tanzania through the Ministry of Lands, Housing and Human Settlements Development (MLHHSD) implemented a major planned land provision scheme in the city of Dar es Salaam that was the largest in the country's history. The scheme was entirely home grown and, unlike other schemes undertaken before, it relied entirely on internal resources including finance and manpower.

This paper analyses this 20,000 Plots Project undertaken in Dar es Salaam from 2003 from a good governance point of view. The Project has received considerable attention from researchers and academics and has also been the pride of politicians (Wanzala, 2007; Mkenda, 2006; Ngama, 2006; Tiba et al., 2005; UN-Habitat, 2010; Mwiga, 2011). The point of departure for this paper is to evaluate whether principles of good governance were followed in implementing the project and with what results. Besides, the paper analyses whether the Project achieved its own stated objectives.

\subsection{Urbanization and the Provision of Planned Land for Development in African Cities}

Africa is the least urbanized of the continents but it is urbanizing fast both from rural to urban migration and increasingly, from natural growth. Managing this rapid urban growth has been a major headache for both local and urban governments and this has seen massive growth of unplanned settlements in terms of the urban population accommodated in, and the geographical area covered by, these undesirable but necessary informal settlements. Data on the countries of the East African Region of Africa indicates that the majority of the urban population lives in slums (Table 1).

Eastern African cities are characterized by pockets of planned areas in a mosaic of informal areas and a high level of slums and urban sprawl, with limited institutional capacity to regulate, administer and manage housing and land use development; in what has been referred to as an ineffective and dual (formal and informal) land management system. This presents governments with many local challenges especially in ordering land uses and provision of infrastructure and access to services. Consequently, while isolated patched of planned urban spaces exist in terms of residential, commercial, institutional, industrial and corridor developments, these remain largely

Table 1. Percentage of urban population living in slums in some countries in Eastern Africa.

\begin{tabular}{ccc}
\hline & \multicolumn{3}{c}{ \% of urban population living in slums } \\
\cline { 3 - 3 } Country & $\mathbf{2 0 0 5}$ & $\mathbf{2 0 0 9}$ \\
\hline Burundi & 64.3 & \\
Comoros & 68.9 & $68.9^{*}$ \\
Ethiopia & 81.8 & 76.4 \\
Kenya & 54.8 & 54.7 \\
Rwanda & 71.6 & 61.5 \\
Somalia & 73.5 & 73.6 \\
Tanzania & 66.4 & 63.5 \\
Uganda & 66.7 & 60.1 \\
\hline
\end{tabular}

Source: African Development Bank (2014). ${ }^{*} 2007$. 
piecemeal, responding to the needs of a few, usually those households in middle to high income brackets (UN-Habitat, 2014: p. 163).

While urban growth has been fast in happening, public authorities have been engrossed in the traditional approach to land use planning where a master plan is referred to and general and detailed land use plans are prepared to inappropriately high standards and where approval of these plans has to be obtained from the Central Government, usually the Ministry responsible for Lands and Urban Development. These take long to plan and approve and they assume a static or slow-growing development, where land could be acquired, interests thereon cleared and land use planning carried out on a tabula rasa. They are also expensive to prepare.

In any case, it has been observed recently with regard to Tanzania, that all the 5 cities and 18 municipalities in the country do not have a current approved general (land use) plan (Misigaro, 2013). Thus they all lack vision of how the city should grow; making it difficult to have a base on which to lay the future city land use framework.

In most cities of Africa, supply of new formal land is linked to declaring an area to be a planning area ripe for development. This may be a result of extension of city boundaries or of a felt need to have new planned land in peri-urban areas. Governments then use their powers to expropriate land, but the low compensation paid to land owners has generally stalled or greatly slowed down land acquisition through compulsory purchase. If/when land is acquired; it can be planned and surveyed to centrally set standards and where central government approval is necessary. It is after that, that land allocation can be made to applicants.

Governments therefore find themselves caught in a vicious circle. Limited resources, especially money, frustrate land acquisition; and informal land subdivision and development takes place partly in response to demand for land and partly to forestall compulsory acquisition. The latter action makes is even more difficult for public authorities to acquire land since, among other reasons, there would be no adequate resources to pay for it. By the mid-2000s, scholars were talking of informal land delivery systems as being efficient in delivering land for housing in African cities (Rakodi, 2004). As a result, urbanites who want to put their resources in land for sheltering themselves, or as an investment, end up doing so on land that is not planned or serviced by public authorities. To break the jinx, the Tanzanian government, through its Ministry of Lands, conceived a scheme where a huge amount of money was borrowed from the Treasury and sunk into implementing a large planned land project, with a projection that not only would the invested money be recovered, but also a surplus, to beef up the funds for mounting sustainable planned land use plans in various areas to enable orderly urban development, would be realized.

In this paper, it is assumed that government intervention in land markets is justifiable on both economic and social grounds as has been widely discussed in the literature (Cheshire \& Vermeulen, 2008). Among the many reasons justifying government intervention in land markets, is the addressing of equity, income redistribution and poverty alleviation issues. However, given that such intervention can be misused, good land governance becomes very important.

\subsection{Understanding Good Land Governance}

Governance emerged in discussions of development in the late 1980s and has developed considerably since then.

Good governance is about the processes for making and implementing decisions. It is not about making "correct” decisions, but about the best possible process for making those decisions. Good decision-making processes, and therefore good governance, share several characteristics as shown in Table 2. In this case, focus is on public authorities although good governance is also applicable to the private sector.

Benefits of good governance include ownership or buy-in by the population; a sense that justice is being done; a belief that what is being considered has legitimacy; avoidance of corruption and misuse of power; enhancing the confidence of communities in government; better decision-making which is cost-effective, efficient, equitable and sustainable; compliance with legal requirements; and creation of an environment for ethical decision-making. Limitation of adhering to good governance principles include the length of time needed to undertake the necessary information dissemination and consultations; and the problem of reconciling various interests within those affected and with the interests of society at large. Where efficiency is taken to mean implementing a project at least cost, with maximum speed, engaging in good governance ideals can be seen as an impediment.

Yet, any major land development scheme has huge implications for redistributing land values in society; and 
Table 2. Characteristics of good governance.

\begin{tabular}{|c|c|c|c|}
\hline Characteristic & Explanation & $\begin{array}{l}\text { Application to land } \\
\text { development projects }\end{array}$ & $\begin{array}{c}\text { Comments with regard to } \\
\text { the } 20,000 \text { Plots Project }\end{array}$ \\
\hline Accountability & $\begin{array}{l}\text { Officials have a duty to report, } \\
\text { explain and be answerable for the } \\
\text { consequences of decisions made } \\
\text { on behalf of the citizens. }\end{array}$ & $\begin{array}{l}\text { Mechanisms to make land } \\
\text { officials accountable may exist } \\
\text { but they may not be enforced, } \\
\text { or enforced only in the case of } \\
\text { junior officials, since top officials } \\
\text { and politicians find themselves } \\
\text { embroiled in land matters }\end{array}$ & $\begin{array}{l}\text { Accountability was realized } \\
\text { in the form of the Ministry } \\
\text { of Lands being able to repay } \\
\text { fully the large amount } \\
\text { of money borrowed } \\
\text { from the Treasury }\end{array}$ \\
\hline Transparency & $\begin{array}{l}\text { People should be able to follow and } \\
\text { understand the decision-making process. } \\
\text { This will enable them to see clearly how } \\
\text { and why a decision was made--what } \\
\text { information, advice and consultation } \\
\text { was considered, and which legislative } \\
\text { requirements were followed. }\end{array}$ & $\begin{array}{l}\text { Mechanisms exist to realize } \\
\text { transparency regarding public } \\
\text { action on land matters. } \\
\text { Proposed land use changes or } \\
\text { new land use layout schemes } \\
\text { must be made available for } \\
\text { public scrutiny and inputs } \\
\text { but procedures are many times } \\
\text { not followed. Methodologies } \\
\text { used to assess the value of } \\
\text { land for compensation are } \\
\text { usually kept secret }\end{array}$ & $\begin{array}{l}\text { Transparency was wanting } \\
\text { with regard to identification } \\
\text { of project areas, undertaking } \\
\text { aerial photographs, early } \\
\text { selection of project } \\
\text { beneficiaries, rates for } \\
\text { valuation used and the } \\
\text { compensation values } \\
\text { arrived at, }\end{array}$ \\
\hline $\begin{array}{l}\text { Follows the } \\
\text { rule of law }\end{array}$ & $\begin{array}{l}\text { Decisions are in line with relevant } \\
\text { legislation and are within the } \\
\text { powers of the authorities, } \\
\text { and procedures are not } \\
\text { circumvented or short-circuited }\end{array}$ & $\begin{array}{l}\text { There are many examples } \\
\text { where rules and procedures exist } \\
\text { but are not followed or are } \\
\text { translated in ways that } \\
\text { give public officials } \\
\text { the upper hand }\end{array}$ & $\begin{array}{l}\text { Aspects of the rule of } \\
\text { law were circumvented } \\
\text { in procedures for } \\
\text { identifying project areas, } \\
\text { land acquisition, }\end{array}$ \\
\hline Responsive & $\begin{array}{l}\text { Public authorities should always } \\
\text { try to serve the needs of the entire } \\
\text { community while balancing } \\
\text { competing interests in a timely, } \\
\text { appropriate and responsive manner. }\end{array}$ & $\begin{array}{l}\text { Only in rare cases do public } \\
\text { officials conceive land } \\
\text { development schemes } \\
\text { especially on land that has high } \\
\text { value, in the interests of low } \\
\text { income households. The latter } \\
\text { in one way or the other find } \\
\text { themselves removed }\end{array}$ & $\begin{array}{l}\text { Needs of low income } \\
\text { households were not } \\
\text { given significant } \\
\text { consideration }\end{array}$ \\
\hline $\begin{array}{l}\text { Equitable and } \\
\text { inclusive }\end{array}$ & $\begin{array}{l}\text { All members of a community } \\
\text { should feel that their interests } \\
\text { have been considered by Public } \\
\text { authorities in the decision-making } \\
\text { process. This means that all groups, } \\
\text { particularly the most vulnerable } \\
\text { (e.g. low income households), } \\
\text { should have opportunities } \\
\text { to participate in the process. }\end{array}$ & $\begin{array}{l}\text { The interests of vulnerable } \\
\text { groups including women, } \\
\text { tenants, children, sharecroppers, } \\
\text { pastoralists, tenants, migrants } \\
\text { and generally, low income } \\
\text { households are usually ignored } \\
\text { or given highly limited attention. }\end{array}$ & $\begin{array}{l}\text { Interests of tenants and } \\
\text { other non-owning land users } \\
\text { were not taken into consideration } \\
\text { with regard to compensation. } \\
\text { Interests of low income } \\
\text { households in general } \\
\text { were not accorded } \\
\text { significant attention. }\end{array}$ \\
\hline $\begin{array}{l}\text { Effective and } \\
\text { Efficient }\end{array}$ & $\begin{array}{l}\text { Public authorities should implement } \\
\text { decisions and follow processes } \\
\text { that make the best use of the } \\
\text { available people, resources } \\
\text { and time to ensure the best } \\
\text { possible results for the citizens. }\end{array}$ & $\begin{array}{l}\text { Land development schemes } \\
\text { tend to be carried out inefficiently, } \\
\text { characterized by grueling } \\
\text { bureaucracy, lack of co-ordination, } \\
\text { and misuse of resources, } \\
\text { resulting into high costs } \\
\text { which limit replication to scale. }\end{array}$ & $\begin{array}{l}\text { Execution of the project was } \\
\text { effective and efficient with } \\
\text { regard to speed of implementation, } \\
\text { issuing of title in record time, } \\
\text { use of local resources and } \\
\text { expertise, and low unit cost for } \\
\text { the large number o plots produced. }\end{array}$ \\
\hline Participatory & $\begin{array}{l}\text { All those affected by, or interested in, } \\
\text { a decision must have the opportunity } \\
\text { to participate in the process for making } \\
\text { that decision. This can be realized } \\
\text { in a number of ways such as } \\
\text { community members being provided } \\
\text { with information, asked for their } \\
\text { opinion, given the opportunity to } \\
\text { make recommendations or, } \\
\text { in some cases, be part of the } \\
\text { actual decision-making process. }\end{array}$ & $\begin{array}{l}\text { Many public authorities eschew } \\
\text { public participation in land } \\
\text { development matters since } \\
\text { this may lead to delays or } \\
\text { even rejection of planned schemes; } \\
\text { or demand for high compensation. }\end{array}$ & $\begin{array}{l}\text { Public participation was very } \\
\text { much inadequate, limited to } \\
\text { just delivering information in } \\
\text { meetings, of the existence } \\
\text { of the project and of the } \\
\text { government seeking the } \\
\text { cooperation of land owners. }\end{array}$ \\
\hline
\end{tabular}


Continued

\begin{tabular}{|c|c|c|}
\hline Decentralisation & $\begin{array}{l}\text { Aiming, as far as practicable, } \\
\text { to devolve powers of decision } \\
\text { making and implementation to } \\
\text { as low a level of government } \\
\text { as possible }\end{array}$ & $\begin{array}{l}\text { Central governments or agencies } \\
\text { are very powerful in conceiving } \\
\text { and executing land development } \\
\text { leaving local authorities as } \\
\text { on-lookers. Projects conceived by } \\
\text { local authorities tend to be subjected } \\
\text { to central government control which } \\
\text { may frustrate their execution. }\end{array}$ \\
\hline
\end{tabular}

Consideration of wider outcomes of decisions

\author{
Decisions made today may \\ have short and long-term \\ wide-ranging outcomes which \\ need to be considered before \\ action is taken
}

Seeking a common stand between public authorities and the community involved.
The bulk of project conception and implementation was centralized in the Ministry of Lands with local governments as distant observers. Later on, the project was decentralized to select local authorities but without the backup, in terms of resources and political support that the Ministry of Lands enjoyed. Local authorities were not prepared to take over the project areas including land earmarked for public facilities.

\footnotetext{
Many times, it is short-term narrowly defined outcomes that are considered particularly in the case of political expediency. Long-term economic, social and environmental outcomes are ignored or given low priority.

Long-term social, political economic and environmental impacts were not taken into consideration. There was no social or environmental impact assessment to inform the project.
}

Land development projects are characterized by a confrontational attitude between public authorities and the affected communities. Concepts like "land is public", or, "public interests" are used to smother opposing views.

Based on a paper: "What is Good Governance” retrieved from: www.goodgovernance.org.au visited 28 March 2015; and FAO (2007).

in displacing existing residents or changing their socio-economic development strategies in the short and long terms. It is thus important that principles of good governance are adhered to in implementing such projects. We will be using some of the above characteristics of good governance to evaluate the 20,000 Plots Project.

Besides, it has been suggested that a land delivery channel to supply land for housing in African cities could be evaluated using the following six criteria (Table 3).

The 20,000 plots project responds very well to some of the above issues, but does not score well on others.

\section{Methodology}

The paper is based on extensive reading of project preparation, implementation and evaluation documents as well as field research done during and after its implementation. It is also based on interviews with key government officials; participant observation and fieldwork undertaken in three of the Project areas in which a questionnaire was administered to a sample of 200 project affected persons (PAPs).

Government officials who were interviewed for facts as well as their opinion on the Project were mainly from the MLHHSD and the Dar es Salaam Local Government Authorities (LGAs) and included land officers, physical planners, land surveyors, valuers, as well as the Project Manager. Participant observation was realized since the author was actively involved in the public meetings convened by the MLHHSD to get informed about the Project; in land acquisition undertakings and in campaigns for better treatment of land owners. The 200 PAPs who were interviewed using a 29-item questionnaire were randomly selected from the 6 sub-wards in the wards of Bunju, Mbweni and Ubungo in the Municipality of Kinondoni (Figure 1), 66\% of whom were male and 34\% female. In terms of marital status, $64.5 \%$ were married, $17.0 \%$ widowed, $10.5 \%$ divorced, and $8.0 \%$ never married. In terms of age, $51.0 \%$ were over 50 and 24.0\% were between 41 and 50 years old. As for length of stay in the area, $47.5 \%$ were born there and $44.0 \%$ had stayed in the area for 10 or more years. While $55.0 \%$ had acquired their land through purchase, $44.0 \%$ had inherited it.

The sample was representative and yielded reliable data. Questionnaire items are hereby reproduced as Appendix 1 . 

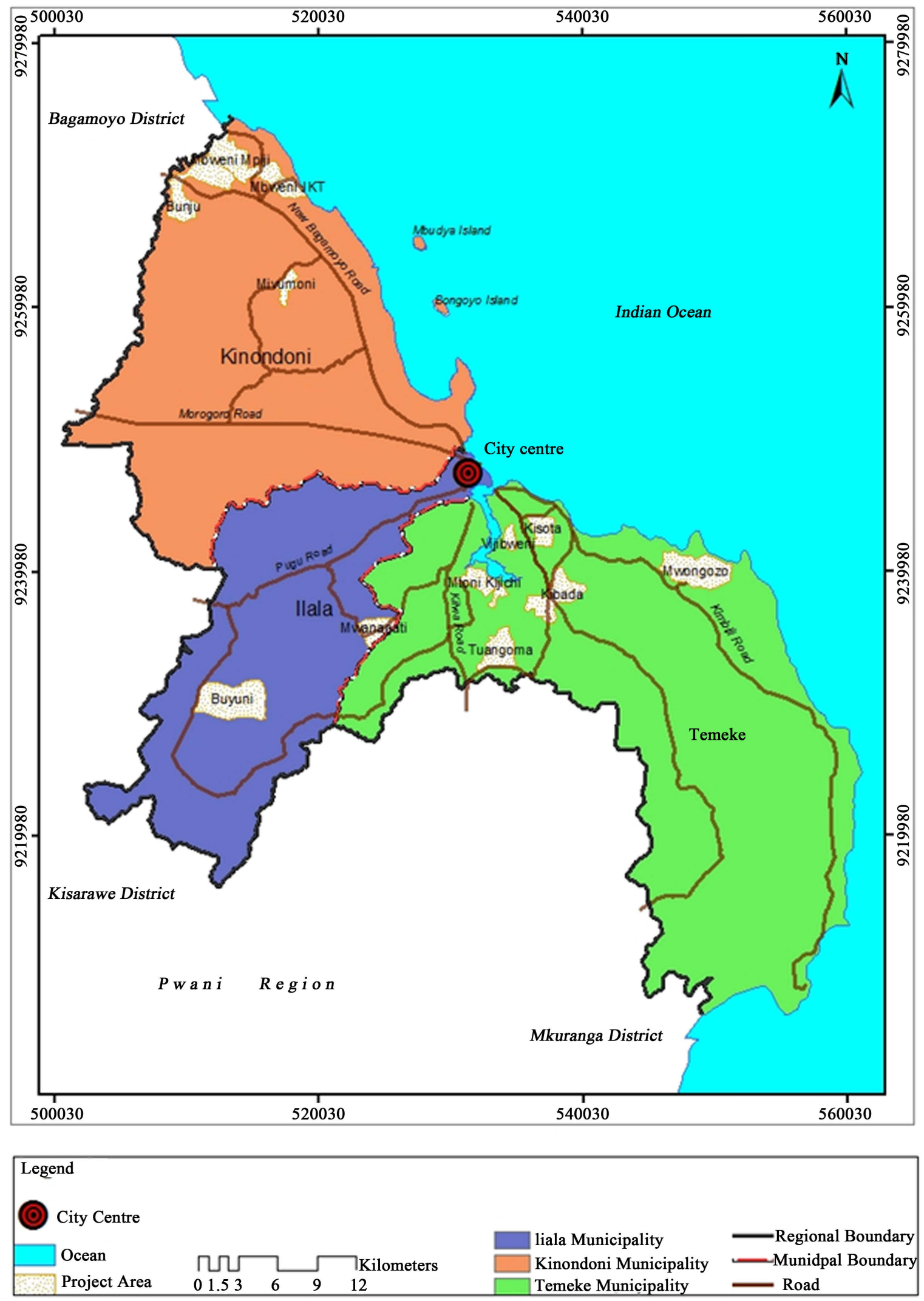

Figure 1. Project areas. 
Table 3. Strengths and weaknesses of a land delivery channel.

\begin{tabular}{|c|c|c|c|}
\hline S No & Criteria & Assessment issues & $\begin{array}{l}\text { Comments with regard } \\
\text { to the } 20,000 \text { Plots Project }\end{array}$ \\
\hline 1. & Scale & $\begin{array}{l}\text { Has the channel delivered land in sufficient volume } \\
\text { and in appropriate locations to meet demand; } \\
\text { is it doing so now; and what are the } \\
\text { prospects of continuing doing so in future? }\end{array}$ & $\begin{array}{l}\text { The number of plots generated } \\
\text { was high but has not been sustained. }\end{array}$ \\
\hline 2. & Cost & $\begin{array}{l}\text { Has the channel delivered housing plots at a cost that } \\
\text { can be afforded by land seekers for housing } \\
\text { especially those in middle and low income categories? } \\
\text { Is it doing so now? }\end{array}$ & $\begin{array}{l}\text { The cost of the plots was generally } \\
\text { beyond the reach of low } \\
\text { income households }\end{array}$ \\
\hline 3. & $\begin{array}{l}\text { Security } \\
\text { of tenure }\end{array}$ & $\begin{array}{l}\text { Has channel delivered plots with sufficient security } \\
\text { of tenure to encourage investment in housing? } \\
\text { What are the threats to security and } \\
\text { can owners deal with them? }\end{array}$ & $\begin{array}{l}\text { Security of tenure for displaced } \\
\text { land owners was compromised. In } \\
\text { comers were given titles } \\
\text { within a short period }\end{array}$ \\
\hline 4. & $\begin{array}{l}\text { Access to } \\
\text { disadvantaged } \\
\text { groups }\end{array}$ & $\begin{array}{l}\text { Has channel in past and today delivered land } \\
\text { to disadvantaged groups including poor } \\
\text { households and poor women? }\end{array}$ & $\begin{array}{l}\text { There was no special consideration } \\
\text { for disadvantaged groups in society. }\end{array}$ \\
\hline 5. & Service provision & $\begin{array}{l}\text { Has the delivery of land been accompanied } \\
\text { by provision of infrastructure and services } \\
\text { either in advance, on subdivision, or subsequently? }\end{array}$ & $\begin{array}{c}\text { Services in project areas } \\
\text { were rudimentary limited to } \\
\text { a few made and many unmade roads }\end{array}$ \\
\hline 6. & Dispute Resolution & $\begin{array}{l}\text { Are there widely available and socially } \\
\text { legitimate means of dispute resolution available } \\
\text { to those accessing and losing land through the channel? }\end{array}$ & $\begin{array}{l}\text { There was no ad hoc dispute } \\
\text { resolution mechanism. Many } \\
\text { complaints went unaddressed. }\end{array}$ \\
\hline
\end{tabular}

Source (with some modifications): Rakodi (2004: p. 4).

\subsection{Background to the 20,000 Plots Project}

Comparing the cost that individuals pay to acquire formally planned land to that of acquiring informal unplanned land, it was argued throughout the 1990s that planned land was highly subsidized, thus denying the government the resources to mount continuous large-scale planned land schemes; and that low income households were in fact paying higher for unserviced land. Planned land, which was pricey, cheap and scarce, invariably ended up in the hands of medium to higher income households, although the idea was to make it accessible to all (Kironde, 2006; Kombe \& Kreibich, 2006).

With regard to Dar es Salaam, it was calculated that the informal sector was producing some 19,000 plots pa to meet the plot shortage emanating from the gap between the number of officially planned plots and the unsatisfied demand gauged from applications for land received by public authorities. This figure informed the 20,000 plots project (Mollel, 2006).

\subsection{Objectives of the 20,000 Plots Project}

The main objective of the project was to make available, 20,000 serviced plots in one year, aiming at solving the problem of shortage of surveyed and serviced plots in the City in a sustainable manner. The specific objectives of the Project were to:

- Alleviate the shortage of surveyed and serviced plots in the City

- Tackle the rapid increase of informal settlements

- Control land speculation

- Address corruption in land offices and in land transaction

- Implement the government's drive to deal with poverty.

- Develop satellite towns that would attract people and create employment and provision of services to the people within the area.

- Implement the ruling Party Manifesto no. 33 (i-ii) that insists on the planning of the towns, surveying, and construction of the better human settlements.

Wanzala (2007: pp. 72-82) 


\subsection{Project Implementation}

Originally, the MLHHSD had planned to implement the Project in the identified areas without recourse to land acquisition since these areas had already been declared to be planning areas way back in 1993 under the Town and Country Planning Ordinance (TCPO). Thus activity started in these areas in June 2002 (See Table 4). However, after resistance from the landowners, and after the questioning of the legality of the 1993 declarations, the government resorted to compulsory land acquisition in November 2002.

A number of considerations were taken into account in determining the areas in which the Project would be implemented. According to the Project Manager, the main factors that were considered on project site identification and selection were:

- Areas which were sparsely developed in terms of buildings were most preferable so as to minimize the compensation costs;

- Environmentally fragile areas in the selected areas were to be reserved and protected.

- Marketability of the planned and surveyed plots i.e. those areas with a potentially high land value and which land seekers would be willing to buy readily, so as to recoup the cost of the Project;

- Proximity and accessibility to social and physical infrastructure;

- Representation, that is, ensuring that each of the three municipalities of Dar es Salaam was included in the Project;

- Difficult and costly areas during planning and provision of infrastructure were to be avoided.

The identification of these areas (Figure 1) was done stealthily before the Project was publicly announced. In August 2002, aerial photographs were taken of all the areas under the Project to record what was on the ground. Inquiries were carried out on land prices in the relevant areas. All these measures were aimed at protecting the Government from unjustified claims for compensation (Mollel, 2006).

\subsection{Project Timelines}

Implementation of the Project was very ambitious and was meant to be completed in one year in accordance with the timelines shown in Table 4.

\subsection{Project Budget}

Since the Project was very much about cost recovery, it is pertinent to look at the budget and expected income. Table 5 shows the Project budget of Tshs 8.9 billion which was "borrowed" from the Treasury on the understanding that it should be repaid in as short a period as possible.

\section{Table 4. Timelines for Project Implementation.}

\begin{tabular}{|c|c|c|c|}
\hline S No & Activity & Duration & Remarks \\
\hline 1. & $\begin{array}{l}\text { Identification of Project areas, } \\
\text { budgeting and project write-up }\end{array}$ & $\begin{array}{c}11^{\text {th }} \text { June-30 } \\
\text { (7 weeks) }\end{array}$ & Carried out by MLHHSD \\
\hline 2. & $\begin{array}{c}\text { Aerial Photographs to record } \\
\text { developments on identified areas }\end{array}$ & $\begin{array}{c}22^{\text {nd }}-23^{\text {rd }} \text { August } 2002 \\
2 \text { days }\end{array}$ & $\begin{array}{l}\text { It is assumed there were no } \\
\text { clouds on these two days }\end{array}$ \\
\hline 3. & Preparation of detailed land use plans & $\begin{array}{l}1^{\text {st }} \text { July } 2002-31^{\text {st }} \text { December } 2002 \\
\text { (6 months) (24 weeks) }\end{array}$ & $\begin{array}{l}\text { Carried out by MLHHSD. Started } \\
\text { before land was acquired }\end{array}$ \\
\hline 4. & Public awareness campaigns & $\begin{array}{c}27^{\text {th }} \text { August- } 21^{\text {st }} \text { September } \\
\text { (31/2 weeks) }\end{array}$ & Time allocated considered inadequate \\
\hline 5. & Acquisition of land by the President & $31^{\text {st }}$ October 2002 & $\begin{array}{l}\text { Notice for land acquisition was } \\
\text { published on } 5 \text { November } 2002 \text { (GN 899) }\end{array}$ \\
\hline 6. & Valuation for determining compensation & started $1^{\text {st }}$ October 2002 & $\begin{array}{l}\text { Valuation started before } \\
\text { land was legally acquired. }\end{array}$ \\
\hline 7. & Land surveying & Started $12^{\text {th }}$ December 2002 & \\
\hline 8. & Engineering works for roads & Started $21^{\text {st }}$ January 2003 & $\begin{array}{l}\text { Excluded drains and water and } \\
\text { electricity infrastructure to reduce costs. }\end{array}$ \\
\hline 9. & Plot allocation & Started $13^{\text {th }}$ March 2003 & \\
\hline
\end{tabular}

Source: Project Office. 
Table 5. Project Budget.

\begin{tabular}{cccc}
\hline $\mathbf{S} / \mathbf{N}$ & Activities & Allocation (Tshs) & \% \\
\hline 1 & Selection and acquisition of project sites & $16,780,000$ & 0.2 \\
2 & Design of plot layouts & $15,567,000$ & 0.2 \\
3 & Valuation & $251,385,250$ & 2.8 \\
4 & Compensation & $5,572,800,000$ & 62.3 \\
5 & Surveying & $898,696,000$ & 10.0 \\
7 & Plot allocation & $187,328,000$ & 2.1 \\
8 & Road construction & $1,877,700,000$ & 21.0 \\
& Project management & $125,234,000$ & 1.4 \\
\hline
\end{tabular}

Source: Project Office.

Table 5 shows that by far the bulk of the Project Budget (nearly two-thirds) was for paying compensation to existing landowners. This is a reflection of the government's awareness of the need to compensate people as the law demands. It is also a result of the realisation that the value locked into the land could only be realised if the land was acquired from current owners and its use changed; and if that land was planned, surveyed and provided with rudimentary infrastructure.

Table 6 shows the Project expenditure and revenue. It needs to be recalled that the project was supposed to be completed in one year. The invested money was recouped several times over (from the selling of plots) and allowed the paying of compensation and instituting rudimentary infrastructure. Later on, sums of money were made available as loans to other local authorities in order to replicate the Project in Dar es Salaam and elsewhere in the country.

Thus, in just over one year, the Tsh 8.9 billion invested had more than trebled, having generated revenue of Tshs 29.3 bn. This is despite that $68.4 \%$ of Project costs went to paying compensation (Table 7). In terms of economics, the Project made sense.

Wanzala (2007) reports that $962 \mathrm{~km}$ of earth roads were provided (at a cost of Tshs 6.7bn), 51 Town Planning layouts were prepared for some 32555 residential and 4000 non-residential plots. Use of modern technology in the form of GPS and total stations reduced surveying time from 6 years to 20 months. The private sector was also included in surveying, property valuation and infrastructure provision.

\subsection{Project Outputs}

The major Project output has been the number of plots planned, surveyed and sold which by 2008 had hit 40,000, twice the planned number. Most of these were residential. This figure exceeds the number of new planned plots produced in all land delivery projects undertaken since independence put together. Table 7 shows the Project outputs in terms of land lots.

Land in Project areas was planned and surveyed and the government was able to give a title to the applicant who had completed the requisite payments within two weeks. Some rudimentary road infrastructure was instituted. Drains, electricity and water networks however were left out. As was the case with the Sites and Services and other land delivery projects, the important issue was to get hold of the land. Servicing usually comes later on, slowly and many times through individual initiatives (Kironde, 1995).

From Table 7 it will be seen that the project areas covered 75,800,000 square meters of land where some 29,291 residential plots were provided. The rest were commercial, public services and religious uses plots. Of significance however, is the low number of high density plots (16.6\%). These are the small ones which could be afforded by low income households and whose unit cost of servicing would be low. At least two reasons can be advanced for this situation. A good number of key government officials did state categorically that low income households were not expected to be able to build. Two, the need to quickly recoup the project money borrowed from the Treasury seem to have convinced project designers to plan low income households out this project, 
Table 6. Project expenditure and revenue (Tshs 000) as of 31st December 2005.

\begin{tabular}{|c|c|c|c|c|c|}
\hline $\begin{array}{c}\text { District or } \\
\text { Municipality }\end{array}$ & Locality & $\begin{array}{c}\text { Compensation } \\
\text { paid }\end{array}$ & $\begin{array}{l}\text { Cost: } \\
\text { road works }\end{array}$ & $\begin{array}{l}\text { Cost: planning, and } \\
\text { surveying; and } \\
\text { overheads }\end{array}$ & Total revenue \\
\hline \multirow{2}{*}{ ILALA } & Buyuni & $2,845,206$ & \multirow{11}{*}{$5,739,000$} & \multirow{11}{*}{$1,955,100$} & \multirow{11}{*}{$26,139,000$} \\
\hline & Mwanagati & $1,430,000$ & & & \\
\hline \multirow{4}{*}{ KINONDONI } & Mbweni Mpiji & $1,820,100$ & & & \\
\hline & Mbweni JKT & 35,900 & & & \\
\hline & Mivumoni & $1,273,300$ & & & \\
\hline & Bunju & $4,426,000$ & & & \\
\hline \multirow{5}{*}{ TEMEKE } & Tuangoma & $1,618,000$ & & & \\
\hline & Kisota & 933,000 & & & \\
\hline & Mtoni Kijichi & 735,300 & & & \\
\hline & Dungu Farm & $1,860,300$ & & & \\
\hline & Vijibweni & 86,600 & & & \\
\hline Outstanding & & 821,600 & $1,200,000$ & 45,200 & $3,205,000$ \\
\hline Totals & & $19,340,400$ & $6,939,000$ & $2,000,300$ & $29,344,000$ \\
\hline$\%$ (of costs) & & 68.4 & 24.5 & 7.1 & \\
\hline
\end{tabular}

Source: Project Office. Note: 1 USD = 1000 Tshs.

Table 7. Project outputs in terms of land lots.

\begin{tabular}{|c|c|c|c|c|c|c|c|c|c|}
\hline \multirow{2}{*}{ Municipality } & \multirow{2}{*}{ Project area } & \multirow{2}{*}{ Size $\left(\mathbf{m}^{2}\right)$} & \multirow{2}{*}{ All plots } & \multirow{2}{*}{ Resid. Plots } & \multirow{2}{*}{ Price/m² (Ths) } & \multicolumn{3}{|c|}{ No of Plots, various Sizes (Densities) } & \multirow{2}{*}{$\begin{array}{l}\% \text { high } \\
\text { density }\end{array}$} \\
\hline & & & & & & High & Medium & Low & \\
\hline \multirow{4}{*}{ Kinondoni } & Mbweni Mpiji & $6,155,115$ & 3544 & 3262 & 1632 & 406 & 1824 & 1032 & 12.4 \\
\hline & Mbweni JKT & $2,419,576$ & 1469 & 1424 & 1920 & 43 & 811 & 570 & 3.0 \\
\hline & Mivumoni & $2,942,461$ & 1508 & 1202 & 1344 & 168 & 652 & 383 & 14.0 \\
\hline & Bunju & $10,738,070$ & 4868 & 4304 & 1760 & 397 & 1542 & 2635 & 8.7 \\
\hline \multirow{6}{*}{ Temeke } & Tuangoma & $7,936,117$ & 3384 & 2892 & 800 & 605 & 1610 & 677 & 20.9 \\
\hline & Kisota & $3,327,616$ & 2362 & 1274 & 1120 & 183 & 609 & 482 & 14.4 \\
\hline & Mtoni Kijichi & $4,465,069$ & 1776 & 1484 & 1280 & 344 & 642 & 498 & 23.2 \\
\hline & Mwongozo & $7,363,421$ & 2754 & 2410 & 1920 & 489 & 1,445 & 476 & 20.3 \\
\hline & Vijibweni & 554,656 & 31 & 25 & & 0 & 1 & 24 & 0.0 \\
\hline & Kibada & $12,540,000$ & 6223 & 2495 & 1500 & 586 & 1452 & 457 & 23.5 \\
\hline \multirow{2}{*}{ Ilala } & Buyuni & $14,130,060$ & 7570 & 6535 & 1056 & 1234 & 3392 & 1909 & 18.9 \\
\hline & Mwanagati & $3,239,570$ & 2164 & 1984 & 704 & 407 & 1170 & 407 & 20.5 \\
\hline Total & & 75,816,731 & 37,653 & 29,291 & & 4862 & 15,150 & 9279 & 16.6 \\
\hline
\end{tabular}

Source: MLHHSD 20,000 Project Reports 2002/2008, Mwiga, 2011.

right from the start. This however is a continuation of land delivery policies going back to the colonial days which have always excluded low income households (Kironde, 1995) and have been project oriented, not based on the comprehensive land use framework for the City. 
Thus it can be concluded that the objective of addressing the shortage of planned plots was achieved but not in one year as had been originally envisaged. Demand was slow. Restriction of allocation of project plots to those without plots in Dar es Salaam had to be abandoned. Payment in installments was allowed. The Project Manager pointed out that while many people showed interests in the plots and filled in application forms, few ended up paying in the required time ${ }^{1}$. Therefore the project had to be extended over one year and replication countrywide was at a lower scale than had been anticipated. Between June 2002 and June 2010, the number of plots surveyed in Dar es Salaam and elsewhere was as shown in Table 8.

The second objective was to tackle the rapid increase of informal settlements. Project areas were saved from developing haphazardly. However, most of the landowners whose land was acquired, especially those in the low income categories ended up moving to nearby unplanned areas and therefore beefing them up (Ngama, 2006: pp. 48-49). Many claimed what they got as compensation could not allow them acquire land in project areas. Moreover, informal areas have continued to grow as the availability of planned plots once again became a problem after the project plots had all been sold.

The third objective was to control land speculation. For a short period when plots to allocate were still abundant, speculation was controlled. However the fact that the majority of the plots that were acquired in 2004 are still undeveloped, suggests speculation. Wanzala (2007) has pointed to the rapid increase of prices of project plots when traded after the initial allocation process ended. In the absence of sustainable supply of new plots to meet demand, speculation has continued and project prices are now more that 20 times what they were in 2004.

The fourth objective was to address corruption in land offices and in land transactions. Although there is continued belief that corruption is rife in the Ministry of Lands (Kamuzora et al., 2009), given that the government flooded the market with thousands of plots, and given the fact that processing of title was speeded up, there is no evidence of corruptive practices during the implementation of the Project.

The fifth objective was to deal with poverty. It was argued that the awarding of titles to land would enable land holders to access finance from financial institutions. However, all indications are that the Project increased poverty among poor land owners and has excluded low income households.

In his evaluation of the Project the Manager said that the Project had made the affected landowners better off and poverty had been put on the run. Our respondents however overwhelmingly state otherwise. Only a tiny percentage considers their condition to be better off; some $13 \%$ consider their situation to be just about the same. However, 85\% said that their situation had become worse compared to their pre-acquisition situation (Table 9). The optimistic statements relating to landowners becoming better off may be referring to a small minority of those whose land was compulsorily acquired.

Most respondents (over 90\%) reported that the land acquisition exercise had adversely affected their ability to generate wealth, and food, and adversely affected their income, and their ability to afford household needs.

The sixth objective was to develop satellite towns that would attract people and create employment and provision of services to the people within the area, as part of efforts to relieve traffic and housing pressure. These were supposed to have a mix of residential and commercial property including high rise buildings, shopping malls, hotels and banking facilities. Areas earmarked for these were Luguruni, Kigamboni, Pugu Kajiungeni,

Table 8. Number of plots under the 20,000 plots project, January 2002 to June 2010.

\begin{tabular}{ccc}
\hline S No & Authority & Surveyed Plots \\
\hline 1. & Dar es Salaam City & 40,000 \\
2. & Mwanza City & 10,000 \\
3. & Morogoro Municipality & 2,700 \\
4. & Mbeya City & 2,390 \\
5. & Bagamoyo Township & 3,000 \\
6. & Kibaha Townshio & 500 \\
\hline
\end{tabular}

Source: Ministry of Lands Records (2015).

${ }^{1}$ Mwananchi, 28 August 2003 and 18 September 2003, p. 2. 
Table 9. Comparing life before and after land acquisition.

\begin{tabular}{ccc}
\hline Comparing life before and after compensation & Numbers & Percentage \\
\hline Better than before & 2 & 1.0 \\
Just about the same & 27 & 13.5 \\
Worse than before & 171 & 85.5 \\
Total & $\mathbf{2 0 0}$ & $\mathbf{1 0 0}$ \\
\hline
\end{tabular}

Source: Fieldwork.

Kongowe, Mji Mwema and Kimbiji to the south and Bunju to the north. However a combination of limited resources, claims for compensation and diverted government interest has limited the implementation of this programme.

The seventh objective was to implement aspects of the ruling party's manifesto. Clearly, the 20,000 plots project had a political agenda of a government wanting to be seen to be doing something about unplanned urban development and that explains why it got cooperation from the highest echelons of government including financial facilities outside normal government procedures, legal backing, and use of various means to ensure the success of the project. Moreover, it was a demonstration of the Presidents advocacy for relying on local resources in development undertakings. Had this project depended on donor funding, it would not have been completed in time for the general election in 2005.

\subsection{Project Outcomes}

The Project seems to have changed the government's attitude towards land administration. For a long time, the government had operated in terms of land allocation, and on the basis that bare land had no value. However, though infrastructural services were rudimentary, the acquisition, planning and surveying of land unlocked its value and this was realised through the sale of planned plots boosting the resources available to public authorities to embark on other planned land delivery projects.

Several local authorities some time in collaboration with financial institutions have undertaken projects to acquire, plan, survey and service, land for sale to the general public and recover the cost. Private sector entrepreneurs have also put resources into assembling and servicing land, sometimes in land sharing arrangements with landowners, and all these have proved profitable. These entrepreneurs however, are complaining of delays in getting approvals from the Ministry of Lands. Also there have been cases of landowners refusing to part with their land unless the public authorities agree to pay them the envisaged full value of the land after its servicing. This has stalled land delivery projects in Kinyerezi and Mivumoni in Dar es Salaam for example.

Another outcome is the exclusion of low income households from planned land schemes because the price for the plots thereon is high. Besides, what landowners get as compensation for their land is relatively low to allow them to acquire a plot in the planned areas. This is leading to social stratification, with the poor being destined to live in unplanned areas. One MP is reported to have complained that the minimum price of Tshs $500,000 /=$ for a Project plot was unaffordable for ordinary Tanzanians. As a result, many of those whose land was taken over for the Project resorted to construction on hazard land and in river valleys ${ }^{2}$.

As a result of the above, growth of unplanned areas has continued and Dar es Salaam continues to depict characteristics of being an unplanned city with enclaves of planned but poorly serviced land surrounded by slums (Wanzala, 2007: pp. 77-78). Indeed, a bird's eye view over Dar es Salaam depicts the well planned 20,000 plots areas surrounded by high density and rapidly growing unplanned areas (Figure 2).

City sprawl has also continued since new projects are undertaken on sparsely occupied land to minimise the cost of its acquisition and this has been perpetrated by developers of new areas for planned land. At the same time, the planned and allocated plots are developed slowly reflecting a combination of factors including lack of development funds on the part of households, poor land servicing, insecurity in new areas, non-enforcement of development control and speculation.

Households whose livelihoods depended on agriculture in the Project areas were completely disenfranchised

${ }^{2}$ Uhuru 11 June 2003, p. 4; Daily News, 11 June 2003, p. 2. 


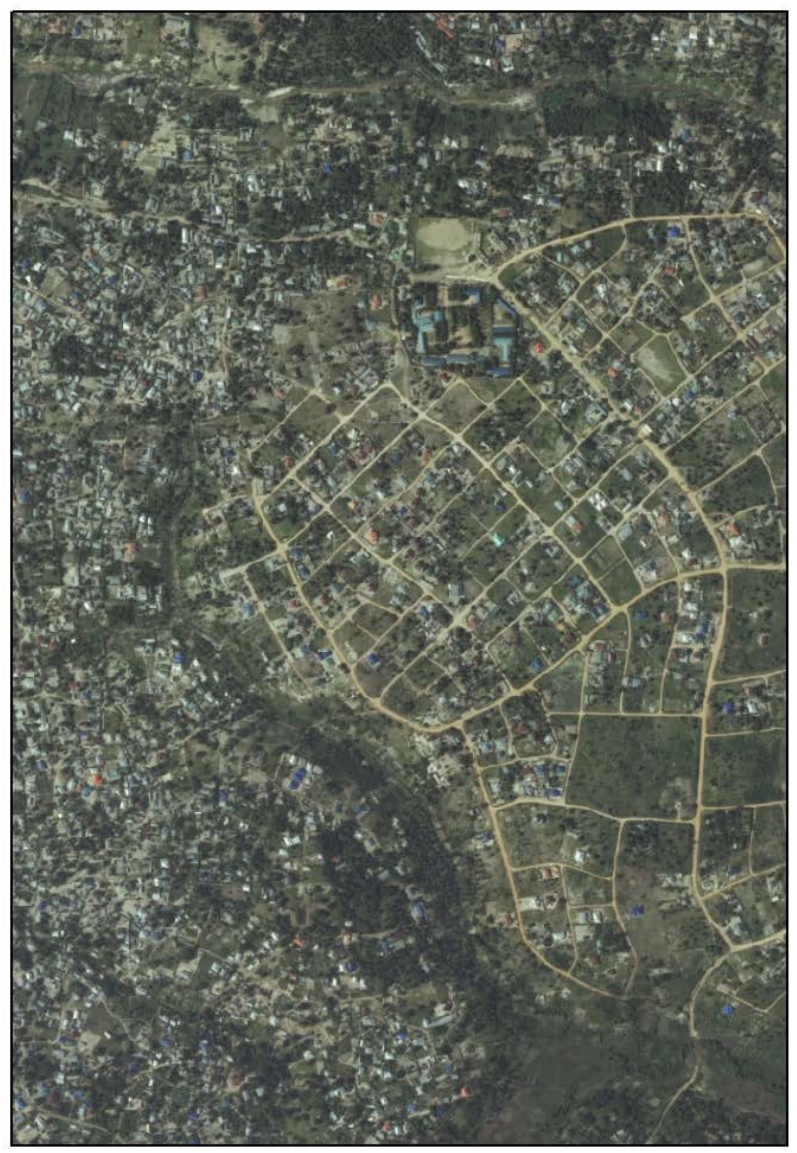

Figure 2. Mwanagati Planned Project area and rapidly growing surrounding informal area. Source: Aerial Photograph 2012.

as the government did not provide for urban agriculture and it was the general agreement by government officials that agriculture was incompatible with urban development. Some displaced persons converted themselves into suppliers of buildings materials such as stone and aggregate to the new incoming builders.

\subsection{Governance Deficits}

The Project had a number of governance deficits. These have been referred to in Table 2 and are identified in at least eight areas that is: Circumventing the law in some cases, limited transparency, centralizing the project in the Ministry of Lands, poor community participation, disregard for environmental outcomes, lack of socioeconomic impact assessment, non-inclusivity, and limited coordination with other relevant institutions

\subsection{Adherence to the Rule of Law}

Originally, the MLHHSD had planned to implement the Project in the identified areas without recourse to compulsory land acquisition powers since these areas had already been declared to be planning areas way back in 1993 through GN 231 meaning that landowners rights except for compensation had automatically ceased. Thus activity started in these areas in June 2002. However, after resistance from the landowners, it was proved that the $1993 \mathrm{GN}$ that had declared these areas to be planning areas was no longer operative since under the TCPO, such a declaration elapses if no planning scheme is prepared within three years. Having realised its circumventing of the law, the government resorted to compulsory land acquisition. Government Notice 899 published on $8^{\text {th }}$ November 2002 gave notice of the President's intention to take over land in named areas.

Earlier on in October 2002, 222 landowners of Mbweni and Bunju had filed a case in the High Court seeking an order to stop the 20,000 Plots Project on the grounds that the Ministry did not follow the law and that their 
interests would be injuriously affected if the Project was implemented ${ }^{3}$. After the government announced the compulsory acquisition of the lands in question in November 2002, all protests regarding the Project fizzled out.

Provisions in the Land Acquisition Act 1967 that require land to be acquired to be precisely defined were not adhered to. This gave room for arbitrary action on the part of the Ministry with regard to the boundaries of these areas, and was a source of uncertainty for many land owners.

The requirement to pay compensation on time was not adhered to in most cases, and there was no remedial action taken as required by the law. It was for example reported that the 20,000 Project had pushed the residents of Mivumoni into poverty because they were prevented from tilling their farms on which they depended for a livelihood, while, despite having their property valued, and despite promises that they would get compensation within two months, a year had elapsed and no compensation had been paid. They were appealing to the President to intervene ${ }^{4}$. This however never happened, so the landowners continued to suffer without bitterness.

\subsection{Transparency}

Many aspects of Project implementation were engulfed in uncertainty and opaqueness. The arrangements leading to the Treasury lending Tshs 8.9bn seems to have been made on a gentleman's agreement with no precedent or standing orders or regulations to be followed. That the money would be recovered was never in doubt and this possibly enabled the arrangement to go ahead, but what was to happen had the Ministry failed to pay the money back? The Treasury thus became a lender without the usual safeguards for lending money. The Ministry of Lands went ahead and began on-lending to other authorities to enable them to mount their own versions of the 20,000 plots projects but many of these soon fell behind in repayment. As of June 2012 the amount owed by 27 authorities as loan repayment to the Ministry of Lands was Tshs 832,241,298/= out of which only 365,609,417/= (44\%) had been repaid and the Ministry did not have an effective system of ensuring recovery (MLHHSD, 2012) on the agreed schedule. In 2015 the Minister for Lands pointed out that four local authorities who the previous year owed Tshs 1.87 billion out of what they had borrowed from the 20,000 Plots Project Fund had effected some payment but still owed Tshs 780.39 million (MLHHSD, 2015: pp. 31-32). Besides appealing to these authorities to pay back the money, the Minister had hinted at holding back land rent due to defaulting local governments and at not approving their land use planning schemes. Thus the lending and on-lending seems to have been done without governing regulations and the money was always at risk.

Identification of areas for the Project and taking aerial photographs over them was done without the knowledge of land owners. Officials justified this as a way of avoiding speculative activity. Nevertheless some landowners complained that since there was a time lag between the taking of aerial photography and valuation, they had continued making developments on their land which were not considered during valuation since they did not show on aerial photographs.

Transparency was also lacking in the valuation exercise where the way the amount of compensation payable was arrived at was not made public and this was a cause of many complaints. After the valuers had taken data on the land and developments to be acquired, owners were told through public announcements after a long wait, that their cheques were ready. These were usually paid at the District Commissioner's offices, a fact that instilled fear among the project affected persons, who had no choice but to accept whatever was assessed for them.

In the early days of plot allocation, the government had required those interested in the plots to fill in application forms. After some time, a list of successful applicants would be produced. However, the criteria for selecting these successful applicants were not made public. This approach was later on abandoned and any applicant with the money to pay was accepted.

\subsection{Centralising the Project in the Ministry of Lands}

The Project was essentially conceived and implemented at the Ministry of Lands although it was depicted as being implemented in collaboration with Dar es Salaam LGAs. The Ministry of Lands was the key player and local government officials felt marginalized. Communities were also not adequately involved and many of their complaints were not addressed. Indeed, communities did not know who to hold responsible for any project outcome adversely affecting them, between the Ministry and Municipalities (Mwakyusa, 2010: pp. 111-114).

\footnotetext{
${ }^{3}$ Mtanzania $23^{\text {rd }}$ October 2002, p. 2.

${ }^{4}$ Mwananchi, 11 October 2003.
} 
This had consequences for the post-implementation management of project areas as local authorities had not been prepared to sustain the Project and to take over the management of the planned areas. Many public spaces and infrastructure such as roads are not being maintained and many of them are back to the bush (Figure 3). Some have been turned into mining sites (Figure 4).

It is notable that no land was planned for local government offices (wards, mtaa) and there was no effort to name the streets, all important aspects of good governance.

The MLHHSD was able to muster a lot of resources to implement the project. When project continuity was passed over to LGAs, the latter only got limited resources and did not have the political backing that the Ministry Lands had. Thus they could not perform the way the Ministry had, and in case of Ilala (Kinyerezi) and Kinondoni (Mivumoni) the municipal authorities were prevented from implementing the project by land owners. The impression that was given and even talked about publicly was that the Central Government as exemplified by the MLHHSD was efficient while LGAs were poor in project implementation. This weakened local governments as well as local governance. Good governance was supposed to see the Project strengthening, not weakening local governments.

\subsection{Poor Community Participation}

The Ministry did mount a public awareness campaign through mass meetings but these were essentially meant for information dissemination but not for exchanging views and coming to a consensus. Thus the Project was characterized by poor community participation. Wanzala (2007: p. 96) found that 70\% of her interviewees complained of not being involved in the Project from the planning stage. They admitted participating in meetings concerning land acquisition but they were not given an opportunity to express their views or give ideas about the Project with regard to their areas. We have noted how area identification and the taking of aerial photographs took place without the knowledge of land owners.

\subsection{Environmental Issues}

The Project did not involve an environmental Impact Assessment. The National Environmental Management Act (2004) section 81 and the $3^{\text {rd }}$ Schedule require an Environmental Impact Assessment for urban development projects. The Project resulted in a lot of environmental degradation as a result of sand mining, burning of natural vegetation, cutting down of trees for fuel and charcoal (Wanzala, 2007: p. 67) and quarrying especially for road aggregates (Figure 5).

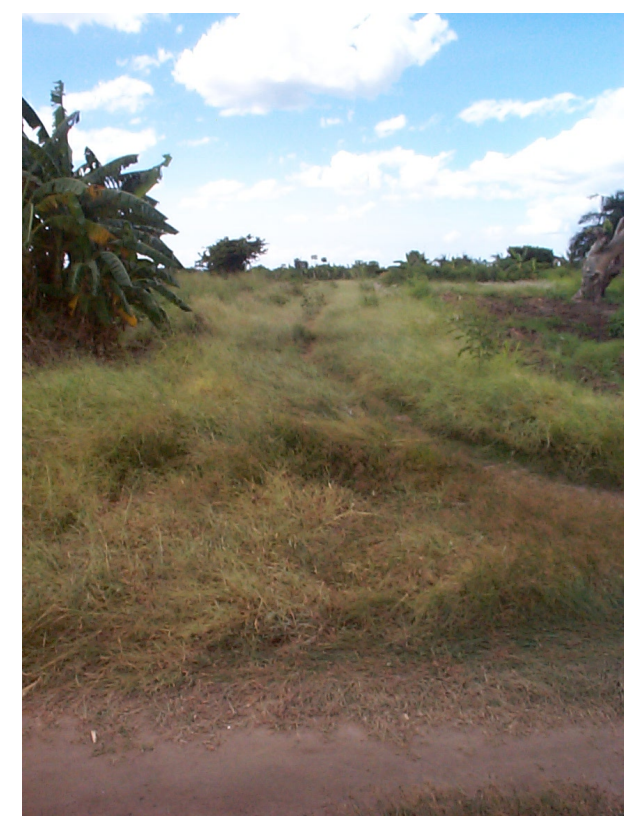

Figure 3. Road reclaimed by bush, Mbweni. 


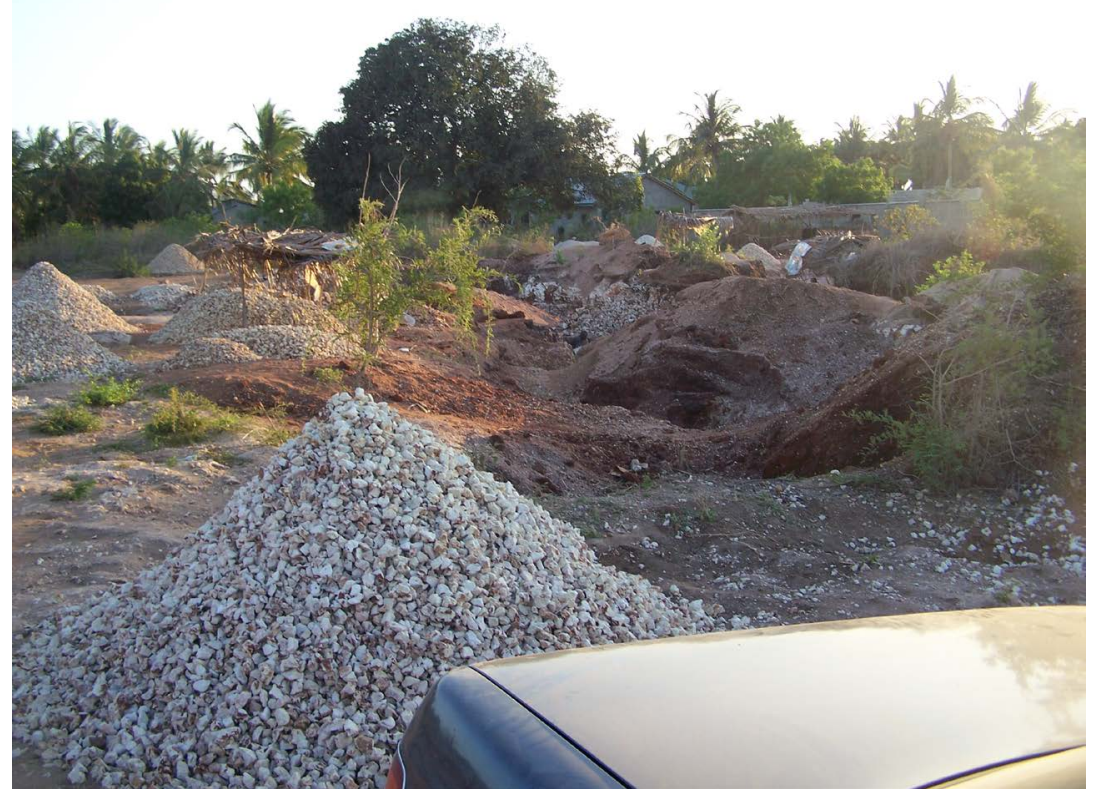

Figure 4. Public land used for mining, Kisota.

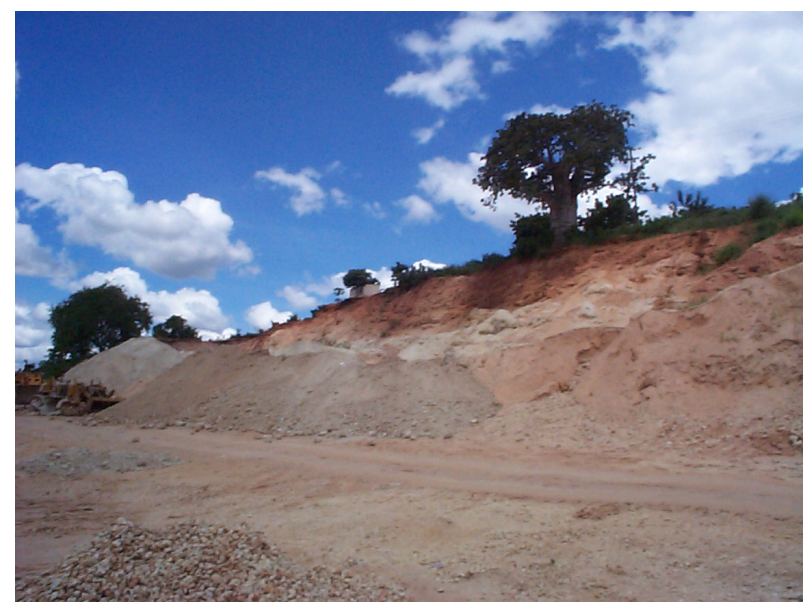

Figure 5. Environmental damage resulting from quarrying for aggregates, Mbweni.

\subsection{Socio-Economic Survey}

No socio-economic assessment was made to ascertain the characteristics of the residents of the areas that were acquired. In terms of access to land, this would have been necessary to establish the pattern of land ownership and to find out the economic activities of the population to be displaced.

For example it was pointed out by residents from Kigamboni that the Project had led to family disputes. One lady narrated that they were given one plot in their shamba which was nevertheless owned with their uncles in Tuangoma. This has led to a major dispute in the family ${ }^{5}$.

Again there were complaints that the Project did not consider livelihood activities of the affected persons particularly urban agriculture which was an important source of livelihood in the project areas. Mkenda (2006: p. 87) points out that $74 \%$ of those displaced in Bunju A and Mpiji were surviving on subsistence farming. An interviewee in Kisota complained:

"The government forgot that the whole family life was depending on those farms by growing various seasonal

${ }^{5}$ Alasiri, February 23, 2003, p. 1, 3. 
crops. These crops sustained our livelihoods in numerous ways. Now we have no farms and our children do not have areas to inherit ${ }^{6}$.

Lack of legal provisions requiring the Minister to carry out a socio-economic assessment may be a reflection of those bygone days when the Government did not think it was imperative to consult people extensively. Nonconsultation was possibly inappropriate since the Government was insisting on good governance, transparency and accountability and it is clear that there are those who suffered excessively as a result of lack of socio-economic impact considerations.

\subsection{Non-Inclusivity}

The focus on monetary issues led to the Project focusing on middle to high income households to the near exclusion of low income households by design. Beneficiaries were mainly those in employment or successful business persons. Only $16.6 \%$ of the plots were high density i.e. small and therefore more affordable to low income households.

The Dar es Salaam Regional Commissioner is quoted as ordering municipal Land Allocation Committees to make sure that they give plots (in Project areas) to people who are capable of constructing homes within two years, urging politicians not to entertain poor people in the very burning issue of plots in their bid to gain popularity:

"Low income people cannot build houses, they are people who rent and we should give plots to people who can construct houses"?

The same sentiments are reported to have been echoed by the Junior Minister for Lands ${ }^{8}$. In practice though, low income households do build, slowly over time but they need to have land first.

Data provided by the Ministry of Lands shows that $32 \%$ of plot beneficiaries were female, $45.5 \%$ were male, $4.5 \%$ went top joint ownership and $18 \%$ went to corporate bodies. The gender ratio was therefore not bad. However, there were no considerations for tenants or those with disabilities.

\subsection{Poor Coordination with Service Providers}

Implementation of the Project was short of co-ordination with key players including Tanzania Electric Supply Company (TANESCO), Tanzania Road Agency (TANROADS) and Dar es Salaam Water and Sanitation Authority (DAWASA). Some of these claimed to have heard about the Project through the media (Mwakyusa, 2010). Indeed it was noted that in the case of DAWASA, the Project was implemented in locations (such as Mivumoni , Buyuni, Kisota, Tuangoma, Kibada and Gezaulole, where the water authority had no immediate or medium term plans to institute water infrastructure (Tiba et al., 2005).

The outcome of this is slow and expensive development, as plot owners have to struggle individually to get service infrastructure to their sites.

\section{Discussions}

Tough leadership marshalling financial and human resources, with legal and political backing did achieve what can go into the country's annals as a major achievement in terms of number of plots produced, and recovery of the cost expended. However, an opportunity was lost to address the wider problems of land use of Dar es Salaam, so that the Project perpetrated the tradition of having patches of planned land over a large mosaic of unplanned land. This, together with the fact that the Project was not replicated to an appreciable scale has meant that the city of Dar es Salaam has continued to grow in terms of informal unplanned areas.

It is amazing that after recording such a success, the steam in providing planned land was lost. Decentralisation to local government was on a small scale and weakly-supported basis. It would appear that the Project had short-term goals of unlocking land values, selling the plots and recovering the money, with a political score in mind.

The use of modern technology demonstrated that land management and administration can be speeded up at a

\footnotetext{
${ }^{6}$ Mr. Mganila a resident who has lived in Kisota before the Project reported in Ngama (2006: pp. 48-49).

${ }^{7}$ Guardian 12 December 2002; Mkenda, 2006: p. 86.

${ }^{8}$ Uhuru 11 June 2003, p. 4; Daily News, 11 June 2003, p. 2.
} 
low cost. Physical data on existing land uses was quickly collected (although sometimes to the disadvantage of affected land owners), and surveying and titling were achieved in record time. This needs to be the norm.

The project depicted governance deficits perhaps because quick outcomes were required. However, it is argued that better land governance would have yielded better outcomes in terms of satisfied communities, inclusive development, strong local governments for perpetrating the land use planning agenda and maintenance of planned areas, hope for a comprehensive land use framework for the city and co-ordination with many other actors. As matters stand, the Ministry accomplished what it had aimed at but the planned areas were left with no basis for sustainable development. It is already ten years later but most of the project land is not developed or is being developed slowly and lacks the necessary physical and social infrastructure. The government too seems to have abdicated its duty of addressing equity, merit goods and income redistribution issues in land administration, in the wake of a major focus on quick financial returns.

\section{Conclusion}

Undertakings like the 20,000 Plots Project in Dar es Salaam can bring relief to the demand for planned land in a rapidly-growing city, but they need to be sustained. Moreover, they need to be inclusive so that members of society particularly those in low income households are not systematically excluded. One approach would be to reduce planning standards to allow for smaller plots, from the current minimum size of $400 \mathrm{~m}^{2}$ to say $200 \mathrm{~m}^{2}$. This would certainly increase affordability. Owners of land that gets taken over also need better treatment in terms of fair compensation and a share in the new developments. The aim must always be to build an inclusive city.

\section{References}

African Development Bank (2014). Gender, Poverty and Environmental Indicators on African Countries. Tunis: Economic and Social Statistics Division.

Cheshire, P., \& Vermeulen, W. (2008). Land Markets and Their Regulations: The Welfare of Economics of Planning. www.lse.ac.uk/geography/AndEnvironment/whosWho/profiles/cheshire/pdfs/Land\%20markets.pdf

FAO (Food and Agricultural Organisation) (2007). Good Governance in Land Tenure and Administration. FAO Land Tenure Studies 9. Rome: FAO.

Kamuzora, P., Ngindo, C., \& Mutasingwa, L. (2009). Tanzania Ethical Issues in Urban Land Administration. Research Report on Strategic Studies on Corruption Submitted to the Prevention and Combating Corruption Bureau (PCCB). Dar es Salaam: Institute of Development Studies, University of Dar es Salaam.

www.tanzania.go.tz/egov_uploads/documents/LAND_REPORT_sw.pdf

Kironde, J. M. L. (1995). The Evolution of the Land Use Structure of Dar es Salaam 1890-1990: A Study in the Effects of Land Policy. Ph.D. Thesis, University of Nairobi, Kenya.

Kironde, J. M. L. (2006). The Regulatory Framework, Unplanned Development and Urban Poverty: Findings from Dar es Salaam, Tanzania. Land Use Policy, 23, 460-472. http://dx.doi.org/10.1016/j.landusepol.2005.07.004

Kombe, W. J., \& Kreibich, W. (2006). Governance of Informal Urbanisation in Tanzania. Dar es Salaam: Mkuki na Nyota.

Misigaro, A. (2013). Orodha ya Halmashauri za Jiji, Manispaa, Wilaya, Miji na Mamlaka za Miji Midogo Zilizo na Mipango ya Jumla (General Planning Schemes). Unpublished Mimeo, Dar es Salaam: Ministry of Lands.

Mkenda, D. S. (2006). The Effects of Dar es Salaam Twenty Thousand Plots Project on the Poor in the Peri-Urban Zone. MSc (Urban Planning and Management) Dissertation, Dar es Salaam: University of Dar es Salaam.

MLHHSD (Ministry of Lands, Housing and Human Settlements Development) (2012). Budget Speech by the Minister of Lands to Parliament, July 2011/2012. Dar es Salaam: Government Printer.

MLHHSD (2015). Budget Speech by the Minister of Lands to Parliament, July 2014/2015. Dar es Salaam: Government Printer.

Mollel, L. (2006). The Rise and Fall of Informal Settlements in Cities. Proceedings of the African Regional Commonwealth Association for Surveying and Land Economy (CASLE) Conference on Sustainable Land Management in Africa, Bagamoyo, 14-17 March 2006, 80-89.

Mwakyusa, P. H. (2010). Towards the Provision of Buildable Housing Land in Tanzania: The Case of the 20,000 Plots Project. MSc (Urban Planning and Management) Thesis, Dar es Salaam: Ardhi University.

Mwiga, B. (2011). Evaluating the Effectiveness of the Regulatory Framework in Providing Planned Land in Urban Areas: The Case of the Dar es Salaam City 20,000 Plots Project, Tanzania. MSc Thesis, Enschede: University of Twente. 
Ngama, R. (2006). Effects of 20,000 Plots Project on Surroundings Neighbourhoods in Dar es Salaam: The Case of Bunju and Boko in Kinondoni Municipality. BSc Thesis, Dar es Salaam: Department of Land Management and Valuation, University College of Lands and Architectural Studies (UCLAS), University of Dar es Salaam (UDSM).

Rakodi, C. (2004). Land for Housing in African Cities: Are Informal Land Delivery Systems Institutionally Robust and Pro-Poor? Paper to Expert Group Meeting (EGM) on Secure Land Tenure: New Legal Frameworks and Tools, FIG Commission 7, UN-Habitat, Institution of Surveyors of Kenya (ISK), CASLE, Nairobi, 10-12 November 2004.

Tiba, A. D., Mwarabu, G., Sikamkono, W. H., Kenekeza, H., Sarehe, S. R., Mwakalinga, V., \& Fyito, V. (2005). The Implication of 20,000 Plots Project on the Emerging form of Dar es Salaam City. MSc Semester Project, Dar es Salaam: Department of Urban Planning and Management, UCLAS, UDSM.

UN-Habitat (2010). Informal Settlements and Finance in Dar es Salaam, Tanzania. Nairobi: UN-Habitat.

UN-Habitat (2014). The State of African Cities 2014. Nairobi: UN-Habitat.

Wanzala, D. A. (2007). Executing a Land Delivery Project: Experience and Lessons from the 20,000 Plots Project. MSc (Real Estate) Dissertation, Dar es Salaam: Ardhi University. 


\section{Appendix 1}

Items of the Questionnaire Administered to 200 Landowners in Bunju, Mbweni and Ubungo Wards, Kinondoni Municipality, Dar Es Salaam

1. Name of the respondent

2. Ward and sub-ward of land ownership

3. Gender

4. Marital Status

5. Age

6. Household size

7. Length of stay on land that was compulsorily acquired

8. How land was acquired by the respondent

9. Evidence of land ownership

10. Literacy and Education levels of the respondents

11. Main occupation of the respondent

12. Income levels of the respondent

13. Whether adequate notice was given before the compulsory acquisition of land

14. The way by which information of land acquisition was relayed to the respondent

15. Time allowed for preparation before vacating the acquired land

16. How information about losing land was received

17. Action taken after the land was acquired by the government

18. Estimate of the wealth that was lost

19. Size of the land that was acquired

20. Degree of involvement in the valuation exercise

21. Amount of compensation that was paid

22. Mode of compensation payment

23. Whether the amount of compensation reflected the land owner's expectation

24. Whether compensation was paid promptly

25. What use was compensation money put to?

26. Whether compensation was adequate to set up a new home

27. Comparing the situation before and after land acquisition

28. Satisfaction with the way the government handles land use matters

29. Knowledge of land laws and procedures 